УДК: 61:004.45

Семенець Андрій Володимирович

Кандидат технічних наук, доцент кафедри медичної інформатики

Тернопільський державний медичний університет ім. І.Я.Горбачевського, м. Тернопіль, Україна

semteacher@gmail.com

Ковалок Володимир Юрійович

інженер-програміст інформаційно-аналітичного відділу

Тернопільський державний медичний університет ім. І.Я.Горбачевського, м. Тернопіль, Україна

kovalok.v@gmail.com

\title{
КОНЦЕПЦІЯ ПОБУДОВИ ІНФОРМАЦИЙНОЇ ІНФРАСТРУКТУРИ МЕДИЧНОГО ВНЗ $З$ ВИКОРИСТАННЯМ ВІЛЬНО-РОЗПОВСЮДЖУВАНОГО ПРОГРАМНОГО ЗАБЕЗПЕЧЕННЯ З ВІДКРИТИМ КОДОМ
}

\begin{abstract}
Анотація. Проаналізовано роль інформаційних технологій в навчальному процесі медичного ВНЗ на прикладі Тернопільського державного медичного університету ім. І.Я.Горбачевського. Запропоновано концепцію побудови інформаційної інфраструктури медичного (фармацевтичного) ВН3, що грунтується на максимальному використанні вільно-розповсюджуваного ПЗ 3 відкритим кодом. Наведено перелік системного, прикладного та спеціалізованого вільно-розповсюджуваного ПЗ 3 відкритим кодом. Продемонстровано можливості застосування вільно-розповсюджуваного ПЗ в галузі охорони здоров'я та медичної освіти. Показано переваги використання технологій віртуалізації апаратного забезпечення та застосування платформо-незалежних веб-додатків. В якості прикладу наведено процес розгортання комплексу веб-додатків у новоствореному мережевому кластері ТДМУ.
\end{abstract}

Ключові слова: медична освіта, програмне забезпечення з відкритим кодом, прикладне програмне забезпечення, інформаційна система, система керування контентом, система дистанційної освіти, віртуалізація.

\section{1. ВСТУП}

Постановка проблеми. Інформаційне середовище кожної сфери діяльності $\epsilon$ фундаментом iї розвитку та показником ефективності. Воно являється сукупністю інформаційних умов існування суб'єкта - наявності інформаційних ресурсів, розвиненості інформаційної інфраструктури, тощо.

У галузі вищої медичної (фармацевтичної) освіти України процес формування інформаційної інфраструктури в останні роки набув великого значення у зв'язку з активним впровадженням різних інформаційних технологій в освітнє середовище. Однією з задач медичної освіти є забезпечення підготовки фахівців, здатних ефективно використовувати можливості сучасних медичних інформаційних систем, брати участь у їх розробці та супроводженні [1].

Аналіз останніх досліджень і публікацій. Роль інформаційних технологій в навчальному процесі ТДМУ. Починаючи з 2005 року в навчальний процес ТДМУ регулярно запроваджуються нові методики та підходи до підготовки майбутніх спеціалістів [2]. Більша частина вказаних методик грунтується на використанні цілого ряду інформаційних технологій та ресурсів $[3,4]$. Нижче показано перелік програмного забезпечення (ПЗ) інформаційних систем та сервісів, що забезпечують навчальний процес в ТДМУ: 
1. Спеціальний веб-сервер в інтранет-мережі університету, на якому публікуються навчальні матеріали (http://intarnet.tdmu.edu.ua) - функціонує 3 2005 року. Сумарний обсяг навчальних матеріалів перевищує 500 Гб.

2. Система дистанційної освіти (СДО) Moodle (http://moodle.org/) - застосовується в ТДМУ з 2007 року. Впродовж наступних років відбувалося наповнення СДО Moodle навчальними матеріалами та адаптація до особливостей здійснення навчального процесу в ТДМУ [5].

3. Починаючи 3 2006-2007 н.p. іспити в ТДМУ проводяться лише у формі бланкового тестового контролю. При підготовці іспиту використовується розроблена Семенцем А.В. "Інформаційна система перевірки знань в медичній освіті" (ICПЗМО) [6]. Програмний пакет (3 додатки) написаний для платформи Windows. Програмістом С. Чекановим додатково розроблені зовнішні модулі (веб-додатки) до ІСПЗМО для підготовки аналітичної інформації та оцінки валідності тестових завдань.

4. Інструментом оцінювання ефективності роботи викладачів університету став веб-додаток "Система рейтингового оцінювання роботи професорськовикладацького складу університету", розроблений професором Марценюком В.П. [7]

5. У 2012 році Семенцем А.В. розроблено систему віддаленого збору статистичних даних для програми "Медицинская регистратура". Вказаний вебдодаток (Java+фреймворк ZK) є одним з елементів оцінювання ефективності функціонування навчально-практичних центрів первинної медико-санітарної допомоги ТДМУ.

Початково всі перелічені сервіси виконувалися на 2 фізичних серверах - ПК на базі процесора AMD Opteron 4122 (4 ядерний) з ОЗП 8 Гб (DDR3). Один (з ОС Debian 6) використовувався для хостингу СДО Moodle, другий (з OC Windows 2003 Server) виконував інші перелічені сервіси (та ще кілька додаткових).

Слід відзначити, що вказана інформаційна інфраструктура мала цілий ряд недоліків, а процес ㄲï експлуатації супроводжувався великою кількістю помилок. В першу чергу, при налаштуванні обох фізичних серверів зовсім не приділялася увага питанням безпеки та захисту інформації. В процесі експлуатації не здійснювалося оновлення операційних систем. Резервне копіювання даних здійснювалося несистематично. Не оптимально використовувалися й апаратні засоби серверів. Вцілому стан інформаційної інфраструктури ТДМУ на кінець 2012 року авторами оцінювався як незадовільний.

Планування реорганізації інформаційної інфраструктури ТДМУ. Результатом вищевказаних недоліків стали суттєві перебої в роботі серверів та втрата частини інформації після серйозної хакерської атаки на комп'ютерну мережу ТДМУ, що відбулася у кінці 2012 року. При ліквідації наслідків атаки авторами було розроблено план реорганізації інформаційної інфраструктури ТДМУ для приведення іiі у відповідність до вимог сучасності. Детально комплекс заходів по реорганізації інформаційної інфраструктури ТДМУ розглядається в роботі [8] i, серед іншого, містить такі етапи:

1. Створення розподіленої інформаційної інтранет-системи університету на базі серверів під керуванням OC Linux.

2. Розділення адміністративної, довідково-інформаційної та навчальної частин веб-сайту ТДМУ, та перенесення їх на нові програмні платформи 3 використанням відомих систем керування контентом (СКК) з відкритим кодом, таких як WordPress (http://wordpress.org/) чи Jomla (http://www.joomla.org/). 
3. Створення системи централізованої авторизації користувачів інформаційної інтранет-системи університету на базі OC Linux 3 встановленим сервером авторизації з сімейства OpenLDAP (http://www.openldap.org/).

На основі вищевказаного плану метою статті $є$ розробка концепції побудови інформаційної інфраструктури медичного (фармацевтичного) ВНЗ з використанням вільно-розповсюджуваного ПЗ з відкритим кодом.

Додатково в роботі презентовано досвід авторів 3 успішного здійснення реорганізації інформаційної інфраструктури медичного ВНЗ шляхом застосування розробленої концепції, на прикладі інформаційної інфраструктури Тернопільського державного медичного університету ім. І.Я Горбачевського.

\section{2. МЕТОДИ ДОСЛІДЖЕННЯ. СКЛАДОВІ ЕЛЕМЕНТИ ІНФОРМАЦІЙНОЇ ІНФРАСТРУКТУРИ МЕДИЧНОГО ВНЗ НА ОСНОВІ ВІЛЬНО- РОЗПОВСЮДЖУВАНОГО ПЗ}

Невід'ємною частиною інформаційної інфраструктури медичного (фармацевтичного) ВНЗ є ії ПЗ, що включає наступні компоненти:

$\checkmark$ Системне програмне забезпечення.

$\checkmark$ Прикладне програмне забезпечення.

$\checkmark$ Методичне програмне забезпечення (електронні навчально-методичні комплекси, електронні мультимедійні підручники, навчальні програми, тощо).

Першочергово, при плануванні, проектуванні та побудові інформаційної інфраструктури ВНЗ слід віддати перевагу застосуванню вільно-розповсюджуваного ПЗ з відкритим кодом. Це дозволяє мінімізувати фінансові затрати на ПЗ i, за рахунок цього - підвищити якісний та кількісний склад апаратної складової інформаційної інфраструктури ВНЗ.

\section{1. Вибір та застосування системного ПЗ.}

Нормальне функціонування інформаційної інфраструктури ВНЗ неможливе без застосування доменної моделі керування мережевою, апаратною та програмною складовими інформаційної інфраструктури ВНЗ. Дана модель може бути реалізована в рамках наступних альтернативних підходів:

> На платформі Linux (рекомендовано): спеціалізовані серверні дистрибутиви + практично будь-які десктопні дистрибутиви. Рекомендується застосовувати дистрибутиви $з$ великим числом впроваджень та чітким планом розвитку. Приклад - сервер Zentyal (http://www.zentyal.org/) - на основі дистрибутиву Ubuntu Server LTS + робочі станції Ubuntu LTS (http://www.ubuntu.com). Для апаратно застарілих ПК варто застосовувати дистрибутив Xubuntu LTS (http://xubuntu.org/getxubuntu/)

$>$ На платформі Windows: дистрибутив Windows Server + налаштування ActiveDirectory + дистрибутив Windows в редакції не нижче Professional + необхідна кількість клієнтських ліцензій (CAL) для доступу користувачів до ресурсів сервера. Дане рішення по зручності та ефективності керування перевершує рішення на платформі Linux, однак вимагає великих фінансових затрат.

Сучасну інформаційну інфраструктуру ВНЗ рекомендовано будувати 3 застосуванням технологій віртуалізації, що дозволяє максимально ефективно використовувати обчислювальні можливості парку серверів [9]. Найбільш перспективною у цьому плані $є$ технологія OpenVZ - віртуалізація на рівні 
операційної системи, яка базується на ядрі Linux. OpenVZ дозволяє на одному фізичному сервері запускати безліч ізольованих копій операційної системи (Virtual Private Servers, VPS або Virtual Environments, VE). На сьогодні однією з найбільш вдалих реалізацій технології є програмне середовище віртуалізації з відкритим кодом Proxmox VE (http://www.proxmox.com/proxmox-ve).

\section{2. Вибір та застосування прикладного ПЗ}

Прикладне ПЗ, що застосовується в системі вищої медичної (фармацевтичної) освіти України можна розділити на дві великі групи:

- ПЗ загального призначення (текстові редактори, редактори електронних таблиць, системи керування базами даних, графічні редактори, веб-браузери, i т.д.).

- ПЗ спеціального призначення для автоматизації професійної діяльності (робота 3 електронними медичними картками пацієнтів, кадровий та бухгалтерський облік, складання розкладу навчальних занять та графіку роботи лікарів, автоматизація бібліотечного фонду і інші спеціалізовані програмні додатки).

Стосовно першої групи - ПЗ загального призначення, то для обох платформ (Windows та Linux) існує велика кількість як комерційних так і вільнорозповсюджуваних програмних додатків. Рекомендується, навіть за умови використання OC Windows в якості прикладного ПЗ загального призначення використовувати вільно-розповсюджуване ПЗ, наприклад:

- офісний пакет Apache OpenOffice (http://www.openoffice.org/) або LibreOffice (http://www.libreoffice.org/);

- графічний редактор Gimp; (http://www.gimp.org/) або інші подібні додатки.

Велика кількість відповідних проектів поширюється через сховище ПЗ 3 відкритим кодом Sourceforge.net (http://sourceforge.net/). Вказаний підхід також дозволяє скоротити фінансові витрати на купівлю ліцензій у порівнянні 3 використанням Microsoft Office.

Розглянемо другу групу - ПЗ спеціального призначення. 3 одного боку, завдяки великій популярності, для платформи Windows розроблено широку номенклатуру різноманітного спеціального ПЗ для автоматизації практично всіх сфер людської діяльності. Причому, є великий вибір як комерційного, так і вільно-розповсюджуваного ПЗ. 3 іншого боку, популярність платформи Windows має наслідком те, що нерідко розробкою ПЗ займаються слабо підготовлені або некомпетентні, як окремі особи, так і цілі організації. Результатом є наявність на ринку ПЗ для платформи Windows великої кількості неякісних, застарілих, або таких, що більше не підтримуються розробниками програмних продуктів.

Інша ситуація склалася стосовно ПЗ спеціального призначення на платформі Linux. Номенклатура ПЗ даної групи тут значно менша. Однак якість програмного забезпечення тут набагато вища. Також, велику частку становить вільнорозповсюджуване ПЗ з відкритим кодом.

Наприклад, у напрямку формування моделі електронного документообігу (ЕД) окремо слід виділити ПЗ з відкритим кодом IC "Alfresco" (http://www.alfresco.com/). Функціональні можливості даної IC перевершують відповідні у комерційного додатку "1C:Документооборот 8" (http://1c.abbyy.ua/products/1c8/docflow/). Однак, є і негативні риси - в першу чергу це необхідність адаптації до вимог законодавства України, яку повинен здійснювати інтегратор власними силами. 
Складною є ситуація з впровадженням медичних інформаційних систем (MIC), i, зокрема, електронних медичних записів (карток) пацієнта (ЕМК) у лікувальних закладах галузі охорони здоров'я України $[10,11]$. Значна частина проектів 3 впровадженням IC ЕMК, особливо у державних та комунальних медичних закладах перетворюється, у кращому випадку, на банальне "винаходження велосипеда" (у гіршому - має корупційні ознаки), і закінчується провалом [11, 12]. Тоді, як, для прикладу, Вікіпедія наводить перелік відкритого ПЗ МIC, що містить більше 20 найменувань [13]. Згадуване вище сховище ПЗ Sourceforge має більше 10 проектів 3 статусом "стабільний додаток" по запиту "EMR" [14], та більше 80 проектів в категорії "Medical Science Apps" [15].

Особливо слід відмітити такі МIC 3 відкритим кодом, як WorldVistA (http://worldvista.org/), та OpenEMR (http://www.open-emr.org/) як такі, що мають великий набір функцій та широко застосовуються в медичних закладах багатьох країн світу. Більше того, існують навіть спеціалізовані дистрибутиви Linux для використання в наукових та медичних установах, зокрема:

- Scientific Linux (http://www.scientificlinux.org/) - спеціалізований дистрибутив, розроблений для використання в науково-дослідних та навчальних закладах. Безпосередньо в дистрибутив інтегровано різноманітне аналітичне ПЗ, а ще більша його кількість доступна через спеціальний репозиторій.

- Ubuntu-Med (http://ubuntuguide.org/wiki/Ubuntu-Med_FAQ) - спеціалізований дистрибутив, розроблений для використання в лікувальних та медичних навчальних закладах. Дистрибутив включає одразу кілька IC електронних медичних записів (карток) пацієнта (ЕМК), ПЗ для роботи 3 медичними зображеннями та інше спеціальне ПЗ.

Окремо автори виділяють спеціалізовані IC для керування науковими публікаціями. Прикладом такої системи є Open Journal Systems (OJS) (http://pkp.sfu.ca/ojs/) - потужна видавнича система 3 відкритим кодом для автоматизації публікації наукових журналів та забезпечення їх автоматичної індексації в спеціалізованих пошукових системах наукового профілю.

\section{3. Вибір та застосування навчально-методичного ПЗ}

Ситуація 3 навчально-методичним ПЗ майже повністю відповідає тій, що склалася в групою ПЗ спеціального призначення, яка розглядалася вище. Для прикладу, Вікіпедія пропонує перелік з більш ніж 40 провідних СДО (часто їх ще називають системи керування навчанням (СКН) чи LMS - Learning management system) світового рівня, 14 з яких - вільно розповсюджуване ПЗ відкритим кодом) [16].

Безперечними лідерами серед ПЗ СДО з відкритим кодом є СДО Moodle (http://moodle.org/) та aTutor (http://atutor.ca/), що мають величезний набір функцій та широко застосовуються в навчальних закладах багатьох країн світу. Зокрема, на сайті спільноти Moodle офіційно зареєстровано більше 100 українських навчальних закладів, що використовують СДО Moodle [17].

Окремо слід відмітити той факт, що практично у кожному ВНЗ ведеться розробка специфічного навчально-методичного ПЗ (чи адаптація існуючого ПЗ), 3 метою максимального пристосування його до особливостей навчального процесу у даному ВНЗ. Прикладом цього $є$ досвід застосування СДО Moodle в ТДМУ та здійснення адаптації даного СДО до особливостей навчального процесу в ТДМУ, які описані в роботах $[3,4,5]$. 


\section{3. РЕЗУЛЬТАТИ ДОСЛІДЖЕННЯ. ПОБУДОВА ІНФОРМАЦИЙНОЇ ІНФРАСТРУКТУРИ МЕДИЧНОГО ВНЗ НА ОСНОВІ ВІЛЬНО- РОЗПОВСЮДЖУВАНОГО ПЗ}

\section{1. Веб-інтегроване середовище інформаційної інфраструктури медичного (фармацевтичного) ВН3}

Сучасні тенденції побудови інформаційної інфраструктури будь-якої організації передбачає перехід на веб-орієнтовані технології та відповідні серверні програмні додатки. Даний підхід зокрема, дозволяє:

$\checkmark$ ліквідувати прив'язку прикладного ПЗ до певної апаратно-програмної платформи;

$\checkmark$ спростити процедуру встановлення, налаштування та адміністрування прикладного ПЗ;

$\checkmark$ ефективно використовувати парк різнорідних робочих станцій, в тому числі і застарілих;

$\checkmark$ з'являється можливість ефективного застосування різноманітних мобільних пристроїв (наприклад, планшетів), що $є$ у власності персоналу ВНЗ та студентів;

$\checkmark$ мінімізувати перелік необхідного ПЗ для робочих станцій (в ідеалі - лише ОС+веб-браузер) та вимоги щодо складності їx налаштування i адміністрування.

Основна трудомісткість такого підходу полягає в процесі налаштування серверної групи, що буде забезпечувати доступ до програмних додатків. При цьому, типовим рішенням є створення мережевих кластерів та застосування технологій віртуалізації серверів, в першу чергу 3 застосуванням програмного середовища віртуалізації 3 відкритим кодом Proxmox VE. Один $з$ прикладів побудови такого кластера у ВНЗ описаний в роботі [18].

В даному випадку (рис. 1), на одному фізичному сервері (hostserver) можуть одночасно ефективно працювати окремі віртуальні сервери (vmserver) число яких може сягати десятків - в залежності від обчислювальних потужностей процесорів та обсягів ОЗП і дискової підсистеми фізичного сервера. Кожен 3 віртуальних серверів призначений для хостингу певного програмного додатку чи системного сервісу. Такий підхід також дозволяє спростити налаштування та адміністрування кожного окремого віртуального серверу у відповідності до вимог лише того ПЗ яке він обслуговує. 

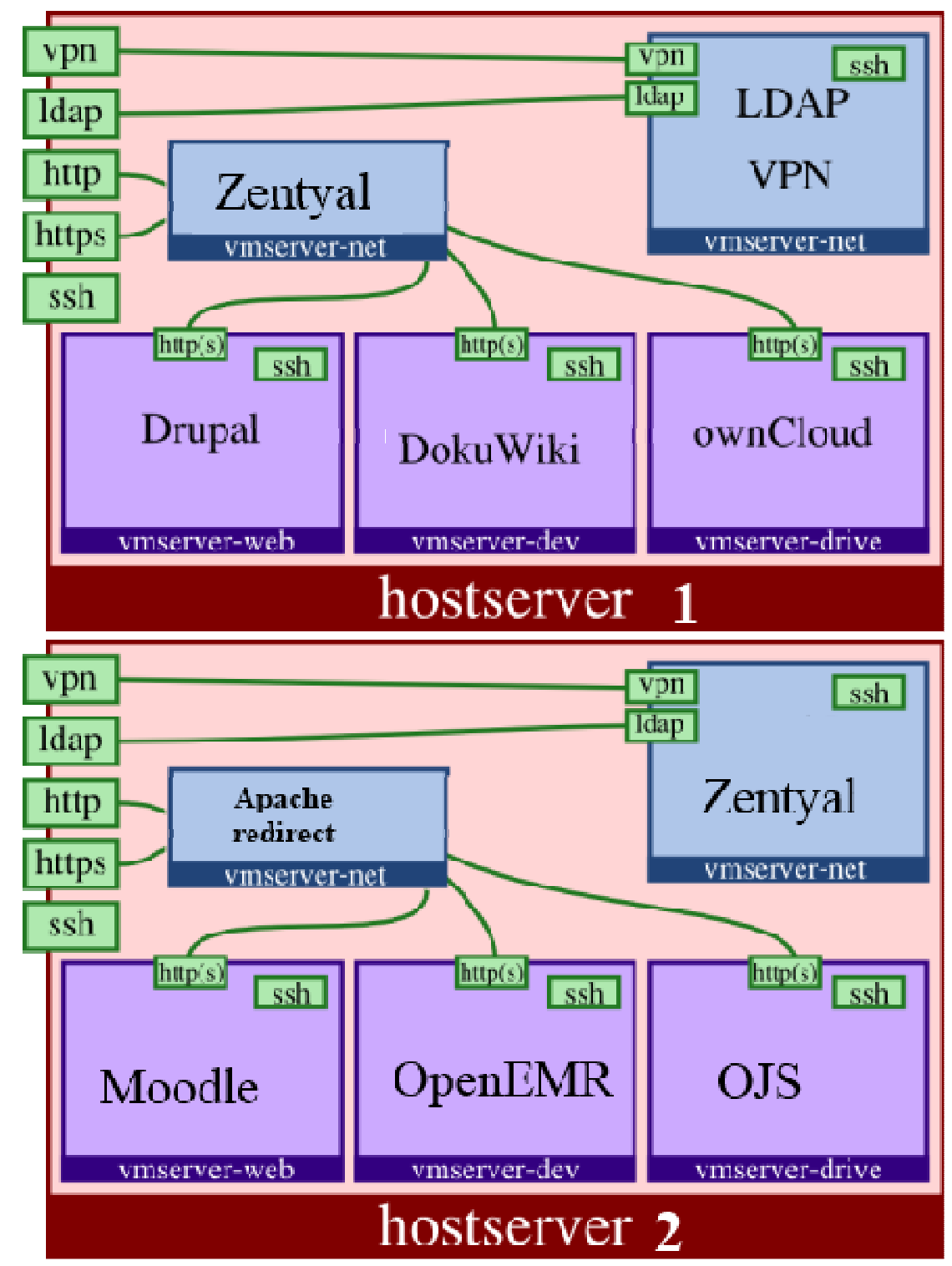

Рис. 1. Мережевий кластер з двох вузлів.

\section{2. Досвід застосування технологій віртуалізації в інформаційній інфраструктурі ТДМУ}

Мережний кластер високої доступності (рис. 2) було створено в ТДМУ на початку 2013 року, за ініціативи авторів, як один з етапів реалізації вищевказаного комплексу заходів по реорганізації інформаційної інфраструктури (п.2.). На початок 2014 року кластер включає 4 фізичних сервери, які об'єднані в єдину структуру за допомогою платформи віртуалізації 3 відкритим кодом Proxmox VE (http://www.proxmox.com/proxmox-ve). 


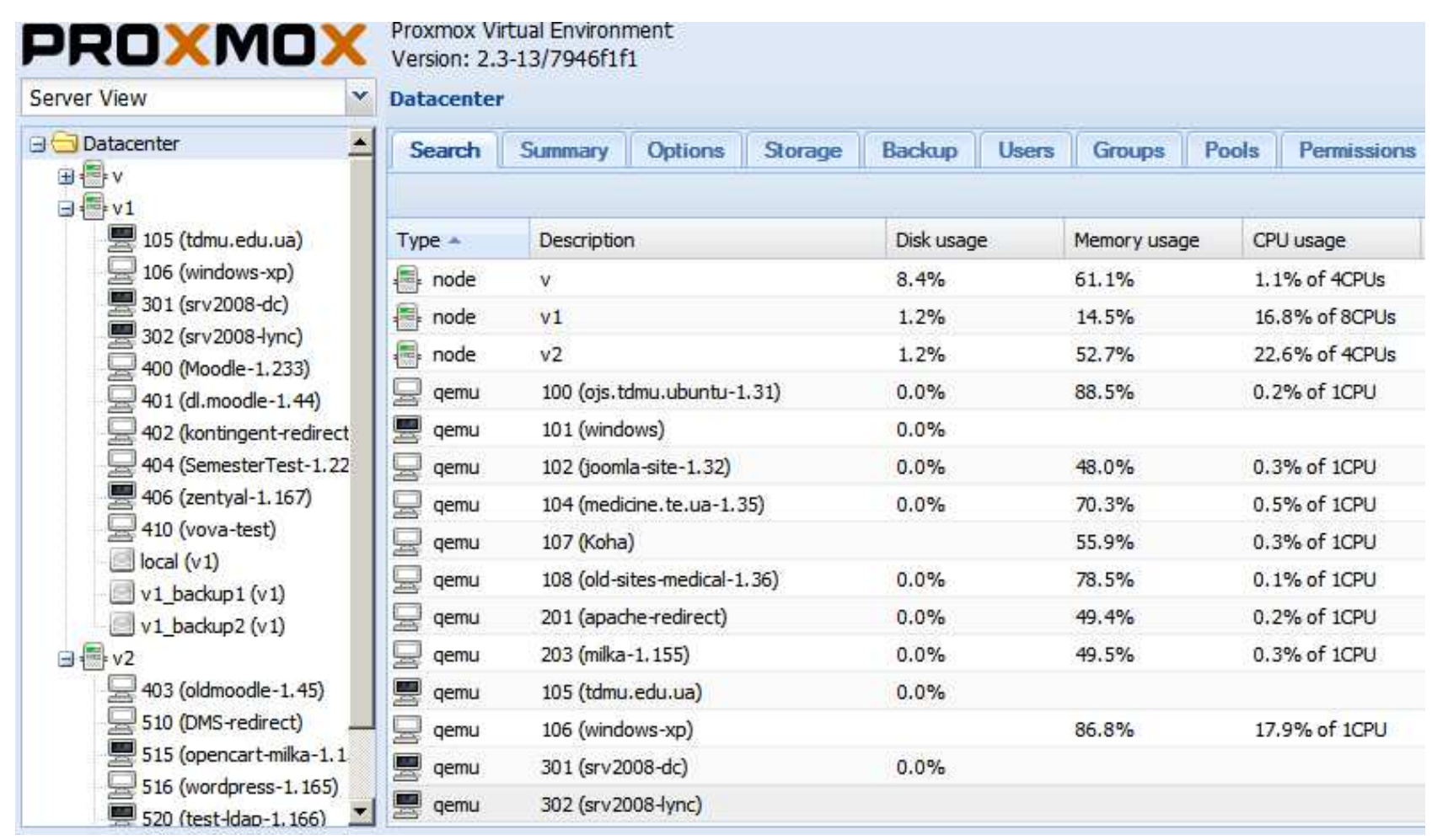

Рис. 2. Мережний кластер ТДМУ на основі платформи віртуалізаиії з відкритим кодом Proxтох VE

В кластері зараз працює 21 віртуальна машина (віртуальні сервери). Частина 3 цих віртуальних серверів працює в експериментальному режимі і являється тестовим платформами для аналізу можливостей застосування тих чи інших нових інформаційних технологій в навчальному процесі ТДМУ. Основна група віртуальних серверів забезпечує функціонування різноманітних сервісів інформаційної інфраструктури ТДМУ (рис. 3). Нижче наведено перелік тих віртуальних серверів, на яких повністю використовується вільно-розповсюджуване ПЗ з відкритим кодом. Причому, тестові сервери в перелік не включалися - лише робочі:

1. Головний сервер СДО Moodle, призначений для публікації електронних версій навчальних курсів та проведення щоденного тестового контролю знань (http://moodle.tdmu.edu.ua);

2. Сервер СДО Moodle центру дистанційного навчання ТДМУ (http://dl.tdmu.edu.te.ua/);

3. Сайт наукових журналів ТДМУ (http://ojs.tdmu.edu.ua/), що працює під керуванням спеціальної СКК з відкритим кодом Open Journal Systems (http://pkp.sfu.ca/?q=ojs);

4. Сайт бібліотеки ТДМУ (http://lib.tdmu.edu.ua/), що працює під керуванням спеціальної СКК з відкритим кодом Koha (http://www.koha.org/);

5. Система ЕДО (https://dms.tdmu.edu.ua/) - використовується для потреб інформаційно-аналітичного відділу і працює під керуванням спеціальної СКК 3 відкритим кодом Alfresco (http://www.alfresco.com/).

6. Сервер-хостинг сайтів деяких окремих підрозділів ТДМУ. Всі розміщені сайти функціонують на базі СКК 3 відкритим кодом WordPress чи Jomla. Для керування хостингом також застосовується ПЗ з відкритим кодом - ISPConfig (http://www.ispconfig.org).

7. Сервер відокремленого сайту інформаційно-аналітичного відділу, що також функціонує на базі СКК з відкритим кодом WordPress (3 спеціальними 
модифікаціями програмного коду, що були здійснені силами співробітників відділу).

8. Сервер навчальних відеофільмів (http://videotube.tdmu.edu.ua/) працює під керуванням спеціальної СКК 3 відкритим кодом ClipBucket (http://clipbucket.com/).

9. Сервер ЕМК ТДМУ (http://openemr.tdmu.edu.ua), де застосовується описане вище ПЗ з відкритим кодом OpenEMR.

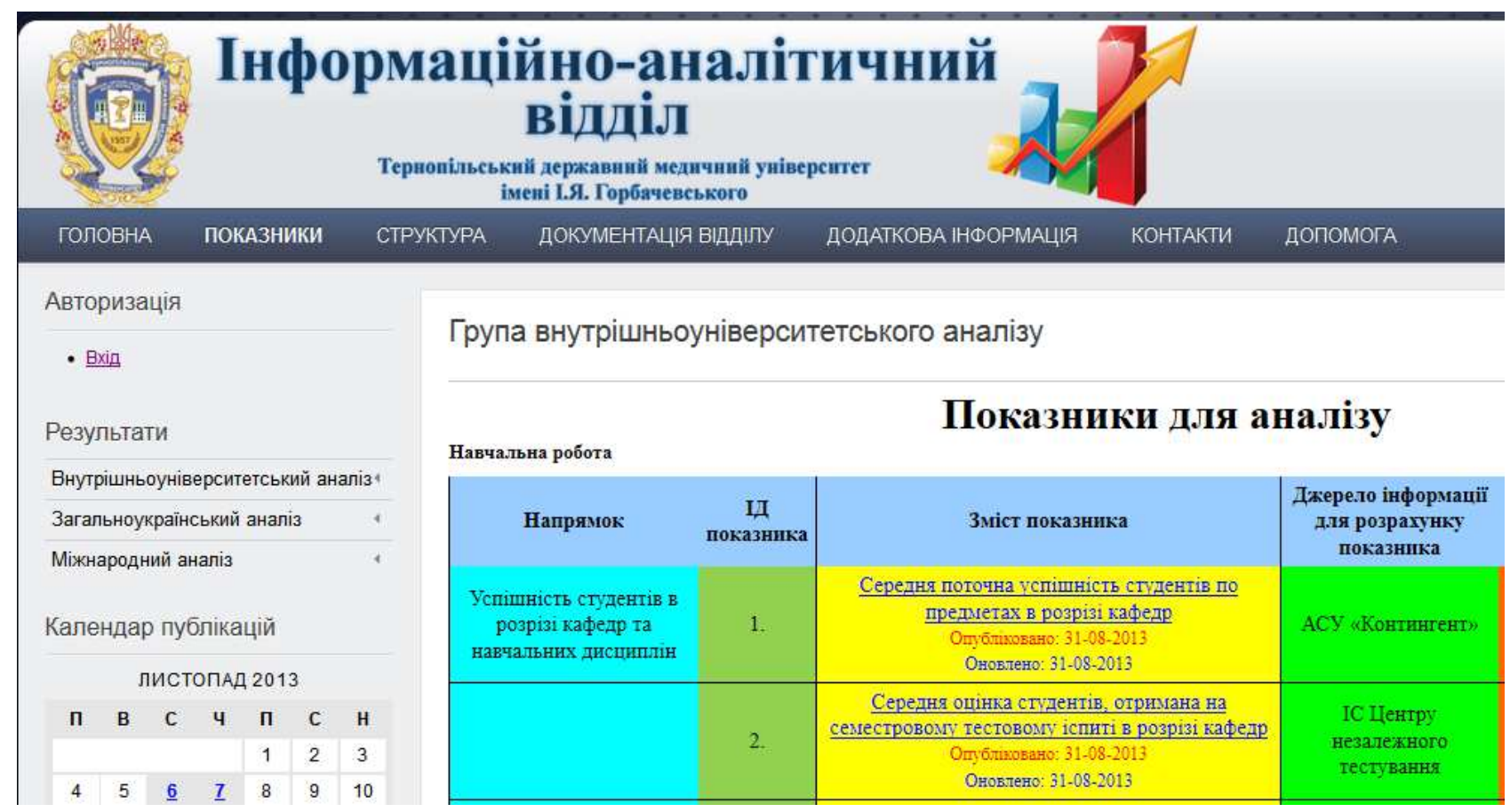

Рис. 3. Сайт інформаційно-аналітичного відділу є одним з прикладів використання СКК WordPress на віртуальному сервері в мережевому кластері ТДМУ

\section{4. ВИСНОВКИ ТА ПЕРСПЕКТИВИ ПОДАЛЬШИХ ДОСЛІДЖЕНЬ}

Впровадження інформаційно-комунікаційних технологій - необхідна умова підвищення якості медичної освіти. Протягом тривалого часу в навчальний процес ТДМУ запроваджуються нові методики навчання, більшість 3 яких грунтується на використанні різноманітних інформаційних технологій. Це передбачає побудову ефективної інформаційної інфраструктури ВНЗ. Невід'ємною частиною інформаційної інфраструктури будь-якого ВНЗ є ПЗ, що складається 3 трьох основних груп: системного, прикладного та методичного ПЗ.

У роботі авторами запропоновано концепцію побудови інформаційної інфраструктури медичного (фармацевтичного) ВНЗ що грунтується на максимальному використанні вільно-розповсюджуваного ПЗ з відкритим кодом. Використання даного ПЗ дозволяє значно скоротити фінансові затрати ВНЗ. При цьому якість і ефективність вказаного ПЗ часто навіть перевищує комерційні аналоги.

Окремо показано переваги, що їх дає використання технологій віртуалізації апаратного забезпечення та застосування платформо-незалежних веб-додатків. Автори додатково підкреслюють можливості ефективного керування інформаційною інфраструктурою медичного ВНЗ у випадку застосування технологій віртуалізації апаратного забезпечення. 
В якості прикладу побудови сучасної інформаційної інфраструктури медичного ВНЗ показано процес розгортання комплексу веб-додатків у новоствореному мережевому кластері ТДМУ.

Таким чином показано, що застосування вільно-розповсюджуваного ПЗ 3 відкритим кодом $є$ складовим елементом сучасного підходу до реалізації навчального процесу в медичній освіті.

\section{СПИСОК ВИКОРИСТАНИХ ДЖЕРЕЛ}

1. Банчук М. В. Сучасний розвиток вищої медичної та фармацевтичної освіти й проблемні питання забезпечення якісної підготовки лікарів і провізорів / [M. В. Банчук, О. П. Волосовець, I. І. Фещенко та ін.] // Медична освіта. — 2007. — № 2. - С. 5-13.

2. Ковальчук Л. Я. Впровадження нової методики навчального процесу в Тернопільському державному медичному університеті імені І. Я. Горбачевського / Л. Я. Ковальчук // Медична освіта. — 2007. — № 2. - С. 16-20.

3. Ковальчук Л. Я. Впровадження в навчальний процес комп'ютерних технологій / Л. Я. Ковальчук, В. П. Марценюк // Медична інформатика та інженерія. - 2008. — № 1. - С. 14-16.

4. Марценюк В. П. Розробка і впровадження системи електронного навчання в Тернопільському державному медичному університеті імені І. Я. Горбачевського / В.П.Марценюк // Медична освіта. - 2008. - № 2. - C. 74-75.

5. Семенець А. В. Адаптація вільно-розповсюджуваного ПЗ з відкритим кодом для підтримки навчального процесу в окремому медичному ВН3. / А. В. Семенець // Медична інформатика та інженерія. - 2013. — № 4. - С. 57-66.

6. Семенець А. В. Методи та програмні засоби оцінки знань в медичній освіті : дис. ... канд. техн. наук : 01.05 .03 / Семенець Андрій Володимирович. — К., 2011. — 163 с.

7. Марценюк В. П. Концептуальні підходи до визначення рейтингу наукової діяльності викладачів ВМ(Ф)НЗ України / В. П. Марценюк, М. І. Швед, С. Я. Гураль // Медична інформатика та інженерія. - 2009. - № 1. - С. 8-13.

8. Семенець А. В. Впровадження інформаційно-комунікаційних технологій - необхідна умова ефективної розробки та супроводження сучасних програмних продуктів. / А. В. Семенець // Кредитно-модульна система організації навчального процесу у вищих медичних (фармацевтичних) навчальних закладах України на новому етапі : матеріали X ювілейної Всеукр. навч.-наук. конф. 3 міжнар. участю (Тернопіль, 18-19 квіт. 2013 р.): у 2 ч. / Терноп. держ. мед. ун-т ім.І. Я. Горбачевського. — Тернопіль : ТДМУ, 2013. - Ч. 1. — С. 455-463.

9. Самойленко А. Виртуализация: новый подход к построению IT-инфраструктуры [Електронний pecypc]. - Режим доступу до документу : http://www.ixbt.com/cm/virtualization.shtml.

10. Качмар В. О. Медичні інформаційні системи - стан розвитку в Україні / В. О. Качмар // Український журнал телемедицини та медичної телематики. - 2010. - Т. 8. — № 1. - С. 67-73.

11. Семенець А. В. Організаційно-методичні підходи впровадження EMR-систем в охороні здоров'я України / А. В. Семенець // Медична інформатика та інженерія. - 2013. - № 3. - С. 35-43.

12. Ошибки при внедрении Корпоративного портала или электронного документооборота серверов [Електронний ресурс]. - Режим доступу до документу : http://habrahabr.ru/post/179731/.

13. List of open-source healthcare software - Wikipedia, the free encyclopedia [Електронний ресурc]. Режим доступу до документу : http://en.wikipedia.org/wiki/List_of_opensource_healthcare_software\#Electronic_health_or_medical_record.

14. Search Results for "emr"- SourceForge [Електронний ресурс]. — Режим доступу до документу : http://sourceforge.net/directory/developmentstatus:production/?q=emr.

15. Download Free Medical Science Apps. Open Source Software - SourceForge [Електронний ресурс]. Режим доступу до документу : http://sourceforge.net/directory/scienceengineering/medical/developmentstatus:production/freshness:recently-updated/.

16. List of learning management systems - Wikipedia, the free encyclopedia [Електронний ресурс]. Режим доступу до документу : http://en.wikipedia.org/wiki/List_of_learning_management_systems.

17. Moodle.org: Registered sites [Електронний pecypc]. - Режим доступу до документу: https://moodle.org/sites/index.php?country=UA.

18. Бикулов Д. Об организации сетевого рабочего пространства в малой сети на уровне виртуальных серверов [Електронний ресурс]. - Режим доступу до документу : http://habrahabr.ru/post/186022/. 


\title{
КОНЦЕПЦИЯ ПОСТРОЕНИЯ ИНФОРМАЦИОННОЙ ИНФРАСТРУКТУРЫ МЕДИЦИНСКОГО ВУЗА С ИСПОЛЬЗОВАНИЕМ СВОБОДНО- РАСПРОСТРАНЯЕМОГО ПРОГРАММНОГО ОБЕСПЕЧЕНИЯ С ОТКРЫТЫМ КОДОМ
}

\section{Семенец Андрей Владимирович}

Кандидат технических наук, доцент кафедры медицинской информатики

Тернопольский государственный медицинский университет им. И.Я.Горбачевского, г. Тернополь, Украина

semteacher@gmail.com

\section{Ковалок Владимир Юрьевич}

инженер-программист информационно-аналитического отдела

Тернопольский государственный медицинский университет им. И.Я.Горбачевского, г. Тернополь, Украина

kovalok.v@gmail.com

\begin{abstract}
Аннотация. Проанализирована роль информационных технологий в учебном процессе медицинского ВУЗа на примере Тернопольского государственного медицинского университета им. И. Я. Горбачевского. Предложен подход к построению информационной инфраструктуры медицинского (фармацевтического) ВУЗа, основанный на максимальном использовании свободно-распространяемого ПО с открытым кодом. Приведен перечень системного, прикладного и специализированного свободно-распространяемого ПО с открытым кодом. Продемонстрированы возможности применения свободнораспространяемого ПО в сфере здравоохранения и медицинского образования. Показаны преимущества использования технологий виртуализации аппаратного обеспечения и применения платформно-независимых веб-приложений. В качестве примера приведен процесс развертывания комплекса веб-приложений в новом сетевом кластере ТГМУ.
\end{abstract}

Ключевые слова: медицинское образование; программное обеспечение с открытым кодом; прикладное программное обеспечение; информационная система; система управления контентом; система дистанционного образования; виртуализация.

\section{A CONCEPTION OF THE MEDICAL UNIVERSITIES INFORMATION INFRASTRUCTURE DEVELOPMENT USING THE OPEN SOURCE SOFTWARE SOLUTIONS}

\author{
Andrii V. Semenets \\ $\mathrm{PhD}$ (technical sciences), associate professor, Department of Medical Informatics \\ I.Ya. Gorbachevsky Ternopil State Medical University, Ternopil, Ukraine \\ semteacher@gmail.com

\section{Volodymyr Yu. Kovalok} \\ Engineer-programmer, Informational-Analitycal Depatrtment \\ I.Ya. Gorbachevsky Ternopil State Medical University, Ternopil, Ukraine \\ kovalok.v@gmail.com
}

\begin{abstract}
The role of the information technologies in the education process of the medical universities based on I.Ya. Gorbachevsky Ternopil State Medical University as example was analysed. A conception of the development of the information infrastructure based on the maximal open source software usage for the medical (pharmaceutical) universities is proposed. Examples of the system and application and specialized open source software are presented. The capabilities of the open source software usage in the healthcare and medical education fields are demonstrated. The advantages of the hardware virtualization and platform-independent web-applications usage are presented. The complex process of the web applications deployment in a new network cluster in the I.Ya. Gorbachevsky Ternopil State Medical University is given as example.
\end{abstract}


Keywords: medical education; open-source software; application software; information system; content-management system; learning management system; virtualization.

\section{REFERENCES (TRANSLATED AND TRANSLITERATED)}

1. Banchuk M. V. Modern development of higher medical and pharmaceutical education and problematic questions of providing of high-quality training of doctors and pharmacists / M. V. Banchuk, O. P. Volosovetsí, I. I. Feshchenko t all // Medical Education. - 2007. — № 2. - P. 5-13 (in Ukrainian).

2. Kovalchuk L. Ya. Introduction of new methods and systems of the educational process in the Ternopil State Medical University named I. Ya. Horbachevsky / L. Ya. Kovalchuk // Medical Education. — 2007. — № 2. - P .16-20 (in Ukrainian).

3. Kovalchuk L. Ya. Computer technologies in medical education / L. Ya. Kovalchuk, V. P. Martsenyuk // Medical Informatics and Engineering. - 2008. — № 1. — P. 14-16 (in Ukrainian).

4. Martsenyuk V. P. The Electronic Education System development and implementation in the Ternopil State Medical University named I. Ya. Horbachevsky / V. P. Martsenyuk // Medical Education. — 2008. — № 2. - P. 74-75 (in Ukrainian).

5. Semenets A. V. Adapting freely distributed, open source software to support the learning process in a separate medical college / A. V. Semenets // Medical Informatics and Engineering. — 2013. — № 4. P. 57-66 (in Ukrainian).

6. Semenets A. V. Methods and software tools for knowledge assessment in medical education.: manuscript ... PhD technical science : 01.05.03 / Semenets Andrii Volodymyrovych. — Kiev, 2011. — 163 p. (in Ukrainian).

7. Martsenyuk V. P. Conceptual approaches for determining rating of scientific activity of Ukrainian medical university porfessors / V. P. Martsenyuk, M. I. Shved, S. Ya. Hural // Medical Informatics and Engineering. - 2009. — № 1. - P. 8-13 (in Ukrainian).

8. Semenets A. V. The introduction of information and communication technologies - a necessary condition for efficient development and maintenance of modern software. / A. V. Semenets // ECTS system of educational process in higher medical (pharmaceutical) educational institutions of Ukraine in the new phase materials tenth anniversary Vseukr. Teach Science. conf. with Intern. participation (Ternopil, 18-19 Apr. 2013): 2 hours / Ternopil. State. Med. Univ im. I. Ya. Horbachevskoho. Ternopol : Ternopil State Medical University, 2013. - Part 1. - P. 455-463 (in Ukrainian).

9. Samoilenko A. Virtualization: a new approach to the IT-infrastructure development [online]. - Available from : http://www.ixbt.com/cm/virtualization.shtml (in Russian).

10. Kachmar V. O. Medical information systems - state of development in Ukraine. / V. O. Kachmar // Ukrainian Journal of Telemedicine and Medical Telematics. — 2010. — Vol. 8. — № 1. — P. 67-73 (in Ukrainian).

11. Semenets A. V. On organizational and methodological approaches of the EMR-systems implementation in the Ukrainian health care / A. V. Semenets // Medical Informatics and Engineering. — 2013. — № 3. - P. 35-43 (in Ukrainian).

12. About errors in Corporate Web-portal or Electronic Document Workflow implementation process [online]. — Available from : http://habrahabr.ru/post/179731/ (in Russian).

13. List of open-source healthcare software - Wikipedia, the free encyclopedia [online]. — Available from : http://en.wikipedia.org/wiki/List_of_opensource_healthcare_software\#Electronic_health_or_medical_record (in English).

14. Search Results for "emr"_ SourceForge [online]. — Available from : http://sourceforge.net/directory/developmentstatus:production/?q=emr (in English).

15. Download Free Medical Science Apps. Open Source Software — SourceForge [online]. — Available from : http://sourceforge.net/directory/scienceengineering/medical/developmentstatus:production/freshness:recently-updated/ (in English).

16. List of learning management systems — Wikipedia, the free encyclopedia [online]. — Available from : http://en.wikipedia.org/wiki/List_of_learning_management_systems (in English).

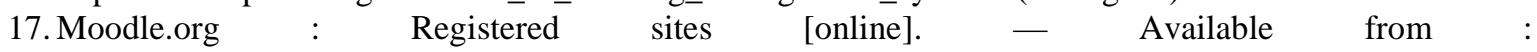
https://moodle.org/sites/index.php?country=UA (in English).

18. Bikulov D. About organization of the small network workspace on the virtual servers level [online]. Available from : http://habrahabr.ru/post/186022/ (in Russian). 